\title{
Joffre Dumazedier and the definition of leisure
}

Published in:

A.J. Veal (2019) Joffre Dumazedier and the definition of leisure. Loisir et Société / Society and Leisure, 42(2), 187-200 (DOI: 10.1080/07053436.2019.1625533)

\begin{abstract}
One of the most widely cited definitions of leisure is that presented by Joffre Dumazedier, originally published in 1962 and based on three functions of leisure identified in his empirical research in France. Three issues are addressed in this paper. First, aspects of the English translation of the definition, published in the USA in 1967, are found to be inappropriate and misleading. Second, attention is drawn to the unexplained omission of experiential features of leisure, also identified in Dumazedier's research. Third, it is observed that, in the 1970s, Dumazedier disavowed his original definition and replaced it with a more exclusive perspective identifying him with the 'Leisure Aristotleans'. Possible reasons for the original omission of experiential dimensions and for Dumazedier's decision to replace his definition with a very different one are discussed, together with consideration of why these matters have been largely ignored by leisure studies scholars.
\end{abstract}

Key words: definition of leisure, Dumazedier, functions of leisure

\section{Introduction}

In any field of academic inquiry, defining the field and its key concepts is of paramount importance. This task is initially undertaken by a few pioneers. In the modern study of leisure, one such pioneer was French sociologist Joffre Dumazedier (1915-2002). In his most well-known book, Vers Une Civilisation du Loisir? (1962), published in translation as Toward a Society of Leisure (1967), he offered a definition of leisure which has been more frequently cited than his views on the leisure society, and continues to be cited (e.g., McClean, Hurd and Rogers, 2005: 34 ${ }^{\mathrm{i}}$; Zuzanek, 2006: 189; Page and Connell, 2010: 136; Taylor, 2011: 17; Kelly, 2012: 21; Godbey and Godbey, 2017: 29). The definition was based on three functions of leisure identified by Dumazedier from his empirical studies in France. This paper draws attention to three issues concerning this definition. First, the appropriateness of parts of the published English translation is questionable and arguably misleading. Second, the definition ignores certain experiential features of leisure which also arose from Dumazedier's research. Third, continued citation of the definition ignores later writings of Dumazedier in which he disavows his iconic definition and adopts a different perspective which identifies him with the 'Leisure Aristotleans' (Van Moorst, 1982). Finally, some observations are offered on possible explanations for Dumazedier's changed views on the definition of leisure and the wider context of leisure studies.

These observations arose from a project concerned with the history of the concept of the 'leisure society', in which Dumazedier played a key role. It was found that contemporary scholars' recollections of discussions of the leisure society idea in the 1960s and 1970s, 
including recollections of Dumazedier's work, are often inaccurate and misleading (Veal, 2011, 2012, 2018). This conclusion arose from a close reading of the leisure society literature of the period aimed at establishing what scholars had actually said about the concept. This naturally included Toward a Society of Leisure as well as some of Dumazedier's earlier and later writings (Dumazedier, 1960, 1971, 1974a, 1989). Since commentators' views on the, nature, desirability or viability of the a leisure society idea depend to some extent on the meaning they attach to the term 'leisure', this exercise included examination of various definitions of leisure, including Dumazedier's. While the substantive nature of Dumazedier's definitional contributions was the primary focus, some observed peculiarities led to exploration of the original French texts, and hence to the identification of the translational issues discussed below.

Before turning to the definition itself, two features of the English version of Dumazedier's book on the leisure society should be noted. The translation was undertaken for US-based publisher Macmillan by Stewart E. McClure (1913-1994), whose varied career included periods as a journalist and as chief clerk of the US Senate Education and Labor Committee. First, the title of the French version of the book referred to a civilization of leisure, whereas the English version refers to a society of leisure. This may not seem significant but in fact, the term used in the body of both the French and English versions of the text is civilization. It is clear that Dumazedier saw a clear distinction between the two terms, since he proposed a programme of cultural development to work towards a future civilization of leisure which he saw as contrasting with the materialist leisure societies which characterised the contemporary Western capitalismt milieu (Dumazedier, 1967: 248; 1998: 149). Second, whereas the title of the original French edition included a question mark, the English translation did not, thus clearly changing the perceived intellectual stance of the book. Jiri Zuzanek (2003) points out that Dumazedier was 'the first one to emphasize that the French title of ... Toward a Society of Leisure, ended with a question mark'. These observations raise the question as to whether Dumazedier approved the translation of the title and, indeed, of the details of the translation of the book as a whole.

The rest of the article is divided into five sections: 1. a reproduction of the 1962/1967 definition, in the original French and as it appeared in English translation; 2. consideration of the translation issues; 3. discussion of an inconsistency in Dumazedier's use of his survey findings to inform his definition; 4. examination of the new definition presented in 1974; and 5. concluding comments on the relationships between Dumazedier's changing views on the definition of leisure and wider theoretical debates.

\section{The 1962/1967 definition of leisure}

Dumazedier's definition was based on a preliminary statement summarising the views of interviewees in his 1950s French urban survey upon which much of his book is based. This statement is presented first. Key features of the statement and of the definition are numbered and italicised to ease the process of comparison. 
However it functions, leisure is first and foremost liberation and pleasure, and it was so indicated by respondents to the 1953 inquiry. Their replies fall into three categories, corresponding to the three major functions of leisure: 1. relaxation, 2. entertainment, 3 . personal development. (Dumazedier, 1967: 14, italics and numbers added)

Si l'on se réfère á l'enquête citée plus haut, presque toutes les réponses établissent que le loisir, quelle se soit son function, est d'abord libération et plaisir. Puis elles se différencient en trois categories qui, selon nous, correspond aux trois fonctions majeures du loisir: fonctions 1 . de délassement, 2 . de divertissement, 3 . de développement. (Dumazedier, 1962: 26, italics and numbers added)

\section{Definition}

Leisure is activity - apart from obligations of work, family, and society - to which the individual turns at will, for either 1. relaxation, 2. diversion, or 3. broadening his knowledge and his spontaneous social participation, the free exercise of his creative capacity. (Dumazedier, 1967: 16-17, italics and numbers added) ${ }^{\mathrm{ii}}$

Le loisir est un ensemble d'occupations auxquelles l'individu peut s'adonner de plein gré, soit pour 1. se reposer, soit pour 2. se divertir, soit pour 3. développer son information ou sa formation désintéressée, sa participation sociale volontaire ou sa libre capacité créative après s'être dégagé de ses obligations professionelles, familiale et sociales. (Dumazedier, 1962: 28, italics and numbers added)

Further evidence on what Dumazedier said, or meant to say, regarding the definition of leisure had appeared in 1960, in an English-language international journal, in which he defined leisure as follows:

Leisure consists of a number of occupations in which the individual may indulge of his own free will - either 1. to rest, 2. to amuse himself, 3. to add to his knowledge or improve his skills disinterestedly, or 4. to increase his voluntary participation in the life of the community after discharging his professional, family and social duties.

(Dumazedier, 1960: 527, italics and numbers added)

In this version, the third function is presented as two, making four functions in total. Dumazedier indicated that this definition was not based on his 1953 survey alone. It also arose from 'comparisons of other surveys', from USA, Netherlands, Germany and Yugoslavia, which had been discussed at a series of seminars organised under the auspices of the International Group for Leisure Social Sciences (IGSSL) iii. However, he observed, without elaboration, that the definition involved a 'problematic approach' which was 'obviously inadequate' (Dumazedier, 1960: 527). It was envisaged that these deficiencies would in due course be addressed by more systematic research on leisure and its relationships with 'other factors in social life' and 'society as a whole' and by a program of action research aimed at 'raising the socio-cultural level of leisure' (p. 530). 
A notable feature of this definition is that it was comprehensive in terms of activity. All activities which might be referred to as leisure in academic discourse and everyday conversation were included. Categories of activity which have sometimes caused difficulties for some scholars, such as harmful or 'deviant' activities, were not excluded.

\section{The functions of leisure: translation issues}

As Lukes (2012) indicates in relation to the work of Durkheim, translation of scholarly works from one language to another can give rise to a number of challenges. In addition to basic competence in two languages, the translator ideally needs to have a grasp of the theoretical milieu of the subject matter and of cultural and literary allusions in the original language. A further layer of complexity is added in this exercise as the process is being examined in the context of half a century of social and cultural change, including development of the field of leisure studies.

Table 1 compares the original French and published English versions of the key terms associated with the three leisure functions. Also included are some additional alternative translations of French terms ${ }^{\text {iv }}$. The three functions are discussed in turn, the first two being relatively unproblematic.

Table 1. Dumazedier's functions of leisure: French and English versions

\begin{tabular}{|c|c|c|c|c|}
\hline & $\begin{array}{l}\text { Vers une civilization du } \\
\text { loisir? (1962) }\end{array}$ & $\begin{array}{l}\text { Toward a society of } \\
\text { leisure (1967) }\end{array}$ & 1960 article (English) & $\begin{array}{l}\text { Alternative } \\
\text { translations }\end{array}$ \\
\hline & \multicolumn{4}{|c|}{ Preliminary, research-based statement } \\
\hline 1 & Délassement & Relaxation & - & Recreation \\
\hline 2 & Divertissement & Entertainment & - & $\begin{array}{l}\text { Diversion, } \\
\text { amusement }\end{array}$ \\
\hline \multirow[t]{2}{*}{3} & Développement & Personal development & - & - \\
\hline & Definition & & & \\
\hline 1 & Se reposer & Relaxation & Rest & Repose, rest \\
\hline 2 & Diverter & Diversion & Amusement & $\begin{array}{l}\text { Entertainment, } \\
\text { amusement }\end{array}$ \\
\hline \multirow[t]{2}{*}{3} & $\begin{array}{l}\text { Développer son information } \\
\text { ou sa formation désintéressée, } \\
\text { sa participation sociale }\end{array}$ & $\begin{array}{l}\text { Broadening his knowledge } \\
\text { and his spontaneous social } \\
\text { participation, the free }\end{array}$ & $\begin{array}{l}\text { 3. Add to knowledge or } \\
\text { improve skills } \\
\text { disinterestedly. }\end{array}$ & $\begin{array}{l}\text { Personal } \\
\text { development }\end{array}$ \\
\hline & $\begin{array}{l}\text { volontaire ou sa libre capacité } \\
\text { creative. }\end{array}$ & $\begin{array}{l}\text { exercise of his creative } \\
\text { capacity. }\end{array}$ & $\begin{array}{l}\text { 4. Increase voluntary } \\
\text { participation in the life } \\
\text { of the community. }\end{array}$ & Volunteering \\
\hline
\end{tabular}

The first function is presented in the preliminary statement as délassement and in the definition as se reposer. Both are translated as 'relaxation'. Délassement has an alternative translation, 'recreation', but, given the complexity of this English word, the translator was probably wise to avoid its use. Se reposer has two alternative English translations: 'repose' and 'rest'. The term 'rest' is of particular interest since it was Dumazedier's own choice in his 1960 paper. This has a further significance, in that it is the term used in Article 24 of the United Nations Universal Declaration of Human Rights, which declares 'the right to rest and leisure' or, in French, 'le droit au repose et aux loisirs'. Dumazedier (1971: 203) was an early defender of the idea of leisure as a human right. 
For the second function, the French word, divertissement (noun)/diverter (verb) is used in both the preliminary statement and the definition. However, in the book it is translated as 'entertainment' in the preliminary statement but as 'diversion' in the definition, while in the 1960 article, the term 'to amuse oneself' is used. The three translations are not exact synonyms, but none seems to alter the original sense of the French version significantly.

The third function is where the major difficulties arise. In the preliminary statement it is presented as développement and translated quite simply and appropriately as 'personal development'. However, in the definition itself the term is replaced by an elaboration, comprising three components: information/education, voluntary activity and creative activity. In this case the translation is problematical. Considering the three components in turn:

a. Information ou formation désintéressée. A literal translation of this phrase is 'information or disinterested training'. The book translation is 'broadening of knowledge', omitting direct mention of 'disinterested training'. In the 1960 article, however, training is included, albeit using the rather awkward term 'improve skills disinterestedly'. The meaning of 'disinterested' in this context is not entirely clear and perhaps this is why the translator of the book omitted it altogether. It could, however, refer to the idea of acquisition of avocational skills, that is skills for enjoyment, as opposed to instrumental vocational skills related to employment. This would reflect Dumazedier's own commitment to adult education (see Dumazedier, 1967: Ch. 10; 1974a: Ch. V-2). The omission of avocational skills training from the translation is, therefore, a departure from the sense of the original.

b. Participation sociale volontaire: In translation, this phrase is presented as 'spontaneous social participation'. This oddly contrived term is clearly inappropriate. For some reason, volontaire is translated as 'spontaneous' rather than 'voluntary'. That the term voluntary was intended is borne out by the 1960 article, which refers to "voluntary participation in the life of the community'v. Clearly, Dumazedier is referring to the activity of volunteering, which reflects his own wider concerns for cultural development and the public's role in it (Dumazedier, 1974a: 177) as well as its significant place in leisure studies discourse (Stebbins and Graham, 2004).

c. Libre capacité creative: The translation of this term as 'free exercise of his creative capacity' is appropriate. However, in the original there is a conjunctive 'or', the omission of which from the translation changes the meaning of the expression.

Thus, what appeared in translation as 'broadening his knowledge and his spontaneous social participation, the free exercise of his creative capacity', would be more appropriately translated as: 'engagement in: the development of knowledge and avocational skills; voluntary activity; or the free exercise of creative capacities'. More succinctly, it could be expressed as 'educational, voluntary or creative activity'. 
The phrase 'après s'être dégagé de ses obligations professionelles, familiale et sociales' appears at the end of the original version of the definition and was translated as 'after meeting of professional, family and social obligations'. In the translation, however, it is inserted near the beginning of the definition. Furthermore, 'après' is translated not as 'after', in a temporal sense, but as 'apart from', in the sense of 'distinct from'. This changes the meaning. The original clearly emphasises the idea of leisure activity as 'residual', that is, only engaged in after other commitments have been attended to, and this is reinforced in the 1960 article. This residual characterisation of leisure is often denigrated by leisure scholars (e.g., Rojek, 1983: 84). The translator, in not giving temporal priority to social obligations, but merely noting their distinctness from leisure, inadvertently enabled Dumazedier to dodge this criticism, at least among Anglophone commentators.

In light of this analysis, while not implying endorsement, a revised rendering of Dumazedier's functional and residual definition could therefore be: 'Leisure is activity in which individuals freely participate for rest, diversion or personal development (including, educational, voluntary and creative activity), after attending to occupational, family and social obligations'.

\section{The experiential dimensions of leisure}

While Dumazedier's formal definition of leisure was structured around three functions of leisure arising from his survey research, the preliminary statement indicates that his research subjects also equated leisure with two experiential concepts: liberation and pleasure. However, Dumazedier excluded these concepts from his purely functional definition. He therefore avoided discussion of the perennially fascinating, and often contested, leisure qualities of liberation/freedom and pleasure. It could be argued that the inclusion in the definition of terms such as 'at will' or 'free will' acknowledges freedom as a dimension. However, such incidental references contrast sharply with the significance accorded to freedom, or perceived freedom in John Neulinger's (1974: 15) widely cited definition of leisure of the era. This definition was psychologically-based but has subsequently been endorsed from a philosophical point of view by Hemingway (1996). The role of liberation/ freedom in conceptualisations of leisure is an issue of perennial debate among sociologists and others. Some include it (e.g., McCormack, 1971; Carr, 2017) while others exclude it (e.g., Rojek, 2010: 189). Similarly, pleasure is only weakly implied in the three functions in Dumazedier's definition, but this also contrasts with other perspectives, for example the link between leisure and the Freudian concept of the 'pleasure principle', as highlighted by Marcuse (1962) and Ferguson (1989). Given the exclusion of, or lack of emphasis on, such significant concepts, it is surprising that Dumazedier's functionally-based definition has been accorded such uncritical prominence.

\section{The disavowal and the new definition}

The disavowal

Dumazedier's later text, Sociology of Leisure (Dumazedier, 1974a), was relevant to the original leisure society project which prompted these comments because of its revelations 
concerning the origins of the title of Toward a Society of Leisure (pp. 211-12). However, it was also relevant to the issue of definitions, since it was impossible to ignore Section III of the book: 'The Quarrel over Definitions'. It included a whole chapter entitled 'Definitions'. The chapter did not give rise to any translational issues ${ }^{\mathrm{vi}}$, but it revealed a radical change in Dumazedier's view of the substantive definition of leisure. In a chapter on 'Origins', he stated, rather surprisingly: 'The reader already familiar with the definition which I derived in $1955 \ldots$ is requested to forget it' (Dumazedier, 1974a: 18). A new definition was outlined but no explanation was offered for this abrupt change. While, as noted above, Dumazedier (1960: 527) had referred to unspecified problems and inadequacies with the earlier definition, these were not identified in this statement of rejection. Before considering an explanation, the new approach to the definition of leisure is outlined below.

\section{The new definition}

Without reference to specific research or literature sources, four functional categories of time-use were presented:

A. remunerated work;

B. family obligations;

C. socio-spiritual and socio-political obligations; and

D. 'activities external to these institutional obligations and mainly oriented to self-fulfilment' (Dumazedier, 1974a: 67).

It would seem that the third of the original functions of leisure, personal development, was covered by category D, although a different term, 'self-fulfilment' (réalisation), was used. However, the first two original functions, rest and diversion/entertainment, were ignored. Dumazedier then considered four alternative definitions of leisure based on various combinations of these time-use categories.

- The first comprised all four categories, including category A, remunerated work. This involved counting the playful or leisure-like activity which can take place during paid work-time as part of leisure. However, this 'state of mind' definition was rejected on the grounds that it was psychological rather than sociological (p. 68).

- Definitions involving categories B and $\mathrm{C}$ were also rejected because, when both are included, leisure is defined as any activity which is not paid work, so it is 'too influenced by economic categories and by those of the sociology of work' (p. 69). Furthermore both categories are ineligible because they involve the element of obligation, to either family or social/political organisations.

- Dumazedier concluded that only category D should be included in the definition of leisure, declaring: 'I prefer to reserve the word leisure for the time whose content is oriented towards self-fulfilment as an ultimate end' (p. 71).

Therefore, only activity which served the third function in the original definition was included in the new formulation. In effect, the bulk of activity previously encompassed by leisure was no longer included: it was classified as mere free time activity. ${ }^{\text {vii }}$ 
Specification of one of the original functions, self-fulfilment, as the sole criterion for leisure initially appeared to retain an element of the functional framework of the 1960s. However, Dumazedier departed from this course in also identifying four 'specific characteristics' of leisure (Dumazedier, 1974a: 73-6). It was claimed that all four also arose from his survey work. While two were the experiential dimensions discussed above, the other two were new.

1. Liberating character. Identified in the 1960 s preliminary statement, but omitted from the original definition, 'liberating character' meant freedom from obligation to institutions, comprising occupational/educational institutions, the family and socio-spiritual and sociopolitical organisations. Free time activity involving any sort of obligation, notably time categories $\mathrm{B}$ and $\mathrm{C}$ above, was therefore excluded from leisure. Curiously, since the family was classified as an institution, activity involving family obligations was effectively excluded, but activity involving obligations to friends was, presumably, included.

2. Disinterested character. This dimension meant that, to qualify as leisure, an activity must not be utilitarian or 'at the service of any material or social end' (p. 74). Any activity which partly served such ends was then categorised as semi-leisure. So the range of time/ activity which had previously been defined as leisure was now effectively divided into three categories: leisure, semi-leisure and free time.

3. Hedonistic character. This could be seen as the second experiential dimension identified by the 1950 s research subjects, pleasure/hedonism. It involved 'a search for a state of satisfaction' (p. 75). The relationship between this and 'self-fulfilment as an ultimate end' was not discussed.

4. Personal character. Leisure was seen as being entirely individualistic, again reiterating independence from institutional commitments. However, that this comes close to acceptance of the previously dismissed psychological perspective is not discussed.

While this definition, with its focus on self-development and four experiential dimensions, is distinctly different to its 1960 s predecessor, it is not clear that Dumazedier fully adopted it himself. For example, an extended discussion of the café as a leisure institution, in the same chapter as the presentation of the new definition, includes reference to 'the general functions of leisure: rest, entertainment or disinterested information' (p. 89). In other discussions in the book, it is not always clear whether the new exclusionary definition of leisure is being used or the old inclusive one.

The new definition can be seen as marking a radical change. A key feature is that leisure is no longer defined in a comprehensive, inclusive sense. The term leisure is 'ring-fenced', being reserved for just those activities which are 'oriented towards self-fulfilment as an ultimate end'. It therefore excludes a ranged of activity which was previously viewed as leisure and continues to be so by other leisure scholars, professionals working in what has become known as the 'leisure industries' and the world at large in common parlance. The remaining activities in this range are classified by Dumazedier as free time activities or, when combined with obligatory activity, semi-leisure. 
This change in Dumazedier's position seems to have been entirely largely ignored by the leisure studies community. Thus, for example, the six recent English-language sources mentioned in the opening paragraph above, which quote the 1960s definition, make no reference to the later definition. Rojek (1985: 86), referring to Dumazedier's 1974 book, comments critically on his approach to sociological definitions of leisure and research methods in general terms, but does not actually cite either of his definitions. Best (2010:4) refers to the 1974 definition but not to its predecessor. For further indication of definitional discussions we might look to a number of recently published handbooks covering the leisure studies field. A 2006 example (Rojek, Shaw and Veal, 2006) included seven citations of Dumazedier, including one referring to the 1967 definition but none to the 1974 version. In two more recent English-language handbooks, on leisure studies (Blackshaw, 2013) and leisure theory (Spracklen, Lashua, Sharpe and Swain, 2017) respectively, Dumazedier is not mentioned at all, suggesting that recognition of his historic role in the development of leisure studies is fading, at least in the Anglophone literature. From the Francophone world, Pronovost and D'Amours (1990) outline five approaches to defining leisure: residual; activity-based; trait-based (e.g., pleasure, spontaneity, play, freedom); cultural; and domainbased (e.g., leisure as distinct from work and family). While Dumazedier's definitions relate to a number of these approaches, the functional approach is not included. Furthermore, while four of Dumazedier's publications are listed in the references, none is cited in the discussion of definitions ${ }^{\text {viii }}$. The authors further advise against seeking a definition of leisure at all (pp. 51, 55). Dumazedier's former colleague, Nicole Samuel (1996: 26) claimed that the 1960s definition had been 'bitterly criticised'ix , but did not refer to the revised version. On the other hand, in an earlier paper she had clearly enunciated the 1974 definition, without mentioning its predecessor (Samuel, 1984: 11). Pronovost (1998: 5) lists the three functions from the original definition and the four experiential characteristics of the revised definition in the same sentence, but does not acknowledge the existence of the two distinct definitions. Thus, despite a reverence for Dumazedier's legacy to the field of study (see Pronovost, AttiusDonfut and Samuel, 1993), the Francophone leisure studies community is less concerned with recording the specifics.

\section{Implications}

In adopting the ring-fenced definition of leisure Dumazedier can be classified as being a member of the group of leisure theorists which Van Moorst (1982) termed, the 'Leisure Aristotleans'. The most extreme member of this group was Dumazedier's almost exact contemporary, Sebastian De Grazia (1917-2002). Curiously, however, Dumazedier did not see his conceptualization as Aristotlean and specifically rejected De Grazia's view that leisure existed in earlier civilizations, observing: 'While spare time, in other words time off work, must obviously be as old as work itself, leisure has distinct characteristics, specific to the civilization born of the industrial revolution (p. 13) ... I am not convinced that the idleness of philosophers in ancient Greece ... can be described as leisure (p. 15)' (Dumazedier, 1974a).

Admittedly, De Grazia's version of the Aristotlean conception is an extreme one. In his seminal work, Of Time, Work and Leisure, he stated: 
Work is the antonym of free time. But not of leisure. Leisure and free time live in two different worlds. We have got in the habit of thinking them the same. Anybody can have free time. Not everyone can have leisure. Free time is a realizable idea of democracy. Leisure is not fully realizable and hence an ideal not alone an idea. Free time refers to a special way of calculating a special kind of time. Leisure refers to a state of being, a condition of man, which few desire and fewer achieve (pp. 7-8)... The world is divided into two classes. Not three or five or twenty. Just two. One is the great majority; the other is the leisure kind, not those of wealth or position or birth, but those who love ideas and the imagination. Of the great mass of mankind there are few persons who are blessed and tormented with this love. ... It is a select, small world of thinkers, artists and musicians not necessarily in touch with one another - who find their happiness in what they do, who can't do anything else, their daemon won't let them (pp. 377-8, emphasis added) (De Grazia, 1962)

This view of leisure is exclusionary and anti-democratic. Indeed, De Grazia (1962: 351) posed the question: 'Are democracy and leisure compatible? The answer: No. In democracy today free time does exist, though in less quantity than is thought: of leisure, there is none'. Clearly, to define leisure so narrowly that it disappears is absurd. As with Dumazedier, De Grazia is widely referenced in the leisure studies literature but this strange conception of leisure seems to have escaped critical attention.

It is certainly the case that Dumazedier did not subscribe to De Grazia's extreme conceptualisation. However, he had a similar view about the state of contemporary culture, declaring that, 'the cultural development of our mass society is enveloped in incoherence and impotence' (Dumazedier, 1967: 243) and free time was in danger of becoming dominated by the 'malignant aspects of leisure à l'américaine' (p. 240). This reflected the critique of the 'culture industry' by Horkheimer and Adorno (1947/2002); indeed, Loosely (2010: 46) observes that 'Dumazedier comes close to classic Adornism'. However, unlike De Grazia, his position was that the tendency could be reversed by means of a programme of state-supported cultural development, which would seek to create a civilization of leisure open to all (Dumazedier, 1967: 248).

While Dumazedier's version of the ring-fencing of the word leisure is democratic, it remains impractical. There is, of course, nothing wrong with devising classification systems for named categories of leisure. Thus, for example, leisure has often been classified along functional lines, including Dumazedier's original rest/diversion/development formulation, Stebbins' (1982) casual/serious categories, and Blackshaw's (2010: 142) devotional (divided into performative and hermeneutic sub-categories) and non-devotional categories. However, to designate just one category of non-work time as 'leisure' and the rest as something else is simply impractical, given modern usage. And yet this approach is quite common in the literature. For example, Elias and Dunning (1986: 96-98) classify activities such as volunteering and hobbies as intermediate spare-time activities, reserving the word leisure for sociable, play and spectator activities. Rojek (2010: 189), drawing explicitly on Aristotle, 
reserves the term leisure for just one category of free-time activity, while other categories, such as consumption and distraction from the 'cares and predicaments of work' (p.189) are excluded. The function of leisure in this restricted view is viewed not as being for selfdevelopment or creativity but as providing a 'school for life' in which people develop their 'competence, relevance and credibility' as workers and consumers in the capitalist world through the exercise of 'emotional intelligence' and 'emotional labour'. Carr (2016: 9), without reference to Dumazedier, reserves the term leisure for free time activity involving the 'search for enlightenment', the remainder being 'leisure which is not leisure', but 'consumerist recreation'. The impracticality of the ring-fencing approach is illustrated in a recent paper, also referencing Aristotle, which argues that, in developing new conceptualisations of leisure required for the emerging 'post-work society', phrases such as "“leisure industries", "leisure venues" and "leisure events" become meaningless' (Snape, Haworth, McHugh and Carson, 2017: 190).

Given that Dumazedier failed to offer a rationale for his change of direction, we might seek a plausible explanation by considering it in the wider context in which he was working. One context is the developing nature of the sociological study of leisure and the other is his own project, which was the two-part vision of a civilization of leisure and an autonomous sociology of leisure.

Regarding the development of the sociological study of leisure, Dumazedier's original definition was clearly functionalist in nature. This theoretical framework fell out of favour in sociology generally in the latter half of the twentieth century, although Roberts (2016: 41) observes that neo-functionalism continues to be the 'standard template for much research' in the field of leisure studies. However, while Dumazedier's definition was functionalist, it would be hard to argue that this was true of his overall theoretical approach. Rather than focussing on the functionalist idea of factors maintaining equilibrium in social systems, Dumazedier's analysis was all about rapid social change and even pending crisis. This may be why later critics of functionalism in leisure studies (e.g., Wearing, 1998; 1-21) have tended to ignore Dumazedier or, if they refer to his work, have not challenged his original definition.

An arguably more plausible explanation for Dumazedier's change of mind could be that he came to realize that his 1960s definition was not really consistent with his leisure civilization project. The latter relied on a normative judgement, that current society, while experiencing expansion in leisure time, activity and consumption, was in need of reform. In a 1989 paper he expressed it as follows: 'The leisure civilization has still to be created. We live in a leisure society, but one that is still far away from the awareness which might create a balance in social time more attuned to the development of both the individual and society' (Dumazedier, 1989: 149). In this formulation, both the current and the transformed society would be characterised by leisure, but distinguished by the descriptors 'society' and 'civilization' respectively. This would then beg the question of how the leisure of the leisure society would differ from the leisure of the leisure civilization. It could therefore have made more sense for current society to have been referred to as a 'free-time society' and for the transformed 
society to be referred to as the 'leisure civilisation'. This would have been the case if the new definition, which distinguished between 'free time' and 'leisure', had been followed to its logical conclusion. In fact, Dumazedier never stated this conclusion but it would have been logical for him to have done so.

One possible reason why Dumazedier did not follow this logical thread could have been that he became preoccupied with a more basic project, namely the establishment of an independent sociology of leisure. Views on the extent to which he succeeded in reaching this goal are very mixed among leisure sociologists. Pronovost (1998:5) noted that 'Dumazedier struggled to develop an autonomous sociology of leisure', suggesting that he had been unsuccessful, but Mommaas-Samuel (1996: 27), to the contrary, claimed that he had successfully 'established leisure as 'an autonomous field of sociological research'. Furthermore, sociology remains one of the major contributors to the field of leisure studies. Research Committee 13 of the International Sociological Association, of which Dumazedier he was the founding chair, is still very active, and was the springboard for the launching in 2018 of the International Journal for the Sociology of Leisure. However, an historical overview of the field in the inaugural issue observed that, within its parent discipline, the sociology of leisure suffers from 'near obscurity' (Stebbins, 2018: 46). Rojek (1985: 93) referred to Dumazedier's 'yearning for a "pure science" of leisure', arguing that this was based on the 'false idea that leisure can be studied semi-autonomously, i.e. as a well-defined sector of social reality, divorced from its societal context'. This is a misleading characterisation of Dumazedier's proposals, although Rojek's comments pre-dated publication of their most detailed exposition. This appeared in the final chapter of Revolution Culturelle du Temps Libre 1968-1988 (Dumazedier, 1988) and in an edited English version in Dumazedier (1989). Here, Dumazedier argued that the sociology of leisure should no longer be treated as a subsidiary of the sociology of work, limited by its 'anachronistic theorisation'. Nor should it be seen as a minor appendage to theory in the traditional sociologies of the family, education, religion or politics (Dumazedier, 1989: 148-150, 158). He argued that leisure was sufficiently significant to merit a sub-discipline in its own right. However, this did not imply that it would be any more 'divorced from its societal context' than the existing sub-disciplinary fields referred to. He speculated that the work of Georg Simmel (1971) on 'individuality' and 'social forms', Friedrich Nietzsche on individuality and creativity and Georges Gurvitch (1964) on ‘social times’ could offer a way forward.

\section{Conclusions}

This paper is concerned with the pioneering, and widely acknowledged, contribution of Joffre Dumazedier to the definition of leisure. Three problematical features of this contribution are, however, identified, one translational and two substantive. The translational issue concerns particularly the curious and misleading treatment of the concept of volunteering in the English version of Dumazedier's definition. The first substantive issue is the unexplained omission of experiential features of leisure from the original definition, even though Dumazedier had identified such features in his empirical research. The second substantive issue is to draw attention to Dumazedier's own disavowal of his original, 1960s, definition and its replacement by a very different version. Identification of such issues might be viewed 
as routine in the development of a relatively new field of enquiry such as leisure studies. What is remarkable in this case is the lapse of time between

Both are concerned with notable of Dumazedier's work to which attention has not previously been drawn two aspects of

The aim of this paper was to draw attention to a number of neglected features of the oft-cited definition of leisure of Joffre Dumazedier, one of the pioneers of leisure studies.

The first observations are concerned with the translational issues arising in the English edition of Dumazedier's seminal Toward a Society of Leisure, notably the confusing treatment of avocational training and volunteering.

The second set of observations are concerned with Dumazedier's substantive contribution to the history of the definition of leisure. It is noted that his 1960s definition, arising from his 1950s surveys, was entirely functional in nature, omitting the experiential qualities of liberation/freedom and pleasure which had also been identified in his survey work. This omission remains unexplained. However, it seemed to be corrected in the 1970s when Dumazedier he repudiated the earlier definition, replacing it with a revised formulation which introduced liberation/freedom and pleasure as leisure characteristics, it also 'ring-fenced' the conceptualisation of leisure, associating it exclusively with self-development and distinguishing it from other forms of free-time activity. Thus, Dumazedier effectively joined the ranks of the Leisure Aristotleans. While the change may be partly explained by developments in sociology, which moved way from functional models, and partly by Curiously, while both his 1960s and 1970s definitions continue to be referenced in the literature, the fact that they represent two distinct approaches goes unrecognised.

\section{Acknowledgements}

I am grateful to Jiri Zuzanek for helpful comments on an earlier draft of the paper and to the anonymous referees for their constructive comments on the original submission.

\section{References}

Best, S. (2010). Leisure studies: Themes and perspectives. London: Sage.

Blackshaw, T. (2010). Leisure. London: Routledge.

Blackshaw, T. (Ed.) (2013). Routledge handbook of leisure studies. London: Routledge.

Carr, N. (2017). Re-thinking the relation between leisure and freedom. Annals of Leisure Research, 20(2), 137-51.

Cosgrove, I., and Jackson, R. (1972). The geography of recreation and leisure. London: Hutchinson.

De Grazia, S. (1962). Of time, work and leisure. New York: Twentieth Century Fund.

Dumazedier, J. (1960). Current problems in the sociology of leisure. International Social

Science Journal, 12(4), 522-533.

Dumazedier, J. (1962). Vers une civilisation du loisir? Paris: Éditions du Seuil.

Dumazedier, J. (1967). Toward a society of leisure. New York: Free Press. 
Dumazedier, J. (1971). Leisure and post-industrial societies. In M. Kaplan \& P. Bosserman (Eds), Technology, human values, and leisure (pp. 191-220). Nashville, TN: Abingdon Press.

Dumazedier, J. (1974a). Sociology of leisure. Amsterdam: Elsevier.

Dumazedier, J. (1974b). Sociologie empirique du loisir: Critique et contre-critique de la civilisation du loisir. Paris: Éditions du Seuil.

Dumazedier, J. (1988). Revolution culturelle du temps libre 1968-1988. Paris: Méridiens Klincksieck.

Dumazedier, J. (1989). France: leisure sociology in the 1980s. In A. Olszewska and K. Roberts (Eds), Leisure and lifestyle: A comparative analysis of free time (pp. 143-161). London: Sage.

Elias, N., \& Dunning, E. (1986). Leisure in the spare-time spectrum. Chapter 2 of: Quest for excitement: Sport and leisure in the civilizing process (pp. 91-125). Oxford: Basil Blackwell.

Ferguson, H. (1989). Sigmund Freud and the pursuit of pleasure. In C. Rojek (Ed.), Leisure for leisure (pp. 53-74). Basingstoke, UK: Macmillan.

Godbey, G., and Godbey, G. (2017). The future of leisure, tourism, and sport: Navigating change. Urbana, IL: Sagamore-Venture.

Griffin, C., Hobson, D., MacIntosh, S., and McCabe, T. (1982). Women and leisure. In J. Hargreaves (Ed.), Sport, culture and ideology (pp. 88-116). London: Routledge and Kegan Paul.

Gurvich, G. (1964). The spectrum of social time. Dordrecht, Holland: D. Reidel Publishing. Hemingway, J.L. (1996). Emancipating leisure: the recovery of freedom in leisure. Journal of Leisure Research, 28(1), 27-43.

Horkheimer, M., and Adorno, T.W. (1947/2002). The culture industry: enlightenment as mass deception. In Dialectic of enlightenment (pp. 94-136). Stanford, CA: Stanford University Press.

Kelly, J.R. (2012). Leisure, $4^{\text {th }}$ Edn. Urbana, IL: Sagamore.

Lanfant, M.-F. (172) Les theories du loisir. Paris: PUF, Collection Le Sociologue.

Loosely, D. (2010). Review essay: Joffre Dumazedier, Toward a society of leisure. International Journal of Cultural Policy, 16(1), 45-47.

Lukes, S. (2012). On translating Durkheim. In M.J. Burke and M. Richter (Eds), Why concepts matter: Translating social and political thought (pp. 193-205). Leiden, Netherlands: Brill.

Marcuse, H. (1962). Eros and civilization. New York: Vintage.

McCormack, T. (1971). Politics and leisure. International Journal of Comparative Sociology, $12,168-181$.

McLean, D.D., Hurd, A.R., and Rogers, N.B. (2005). Kraus' recreation and leisure in modern society, 7th Edn. Boston, MA: Jones and Bartlett.

Mommaas, H. (1997). European leisure studies at the crossroads? A history of leisure research in Europe. Leisure Sciences, 19(4), 241-254.

Neulinger, J. (1974). The psychology of leisure. Springfield, IL: Charles C. Thomas.

Page, S.J., and Connell, J. (2010). Leisure: An introduction. Harlow, UK: Pearson.

Pronovost, G. (1998). Trend report: leisure. Current Sociology, 46(3), 1-22. 
Pronovost, G., Attias-Donfut, C., and Samuel, N. (Eds) (1993). Temps Libre et Modernité: Mélange en l'honneur de Joffre Dumazedier. Sainte-Foy, Québec: Presses d l'Université du Québec.

Pronovost, G., and D'Amours, M. (1990). Leisure studies: a re-examination of society. Loisir et Société, 13(1), 39-60.

Roberts, K. (2016). Social theory, sport, leisure. London: Routledge.

Rojek, C. (1983). Emancipation and demoralization: contrasting approaches in the sociology of leisure. Leisure Studies, 2(1), 83-96.

Rojek, C. (1985). Capitalism and leisure theory. London: Tavistock.

Rojek, C. (2010). The labour of leisure. London: Sage.

Rojek, C., Shaw, S., \& Veal, A.J. (Eds) (2006). Handbook of leisure studies. London: Palgrave.

Samuel, N. (1984). Le temps libre: Un temps social. Paris: Librairie des Meridiens.

Samuel, N. (1996) The prehistory and history of leisure research in France. In H. Mommaas, H. van der Poel, P. Bramham and I, Henry (Eds), Leisure research in Europe: Methods and traditions (pp. 11-37). Wallingford, UK: CAB International.

Simmel, G. (1971). On individuality and social forms. Chicago, IL: University of Chicago Press.

Snape, R., Haworth, J., McHugh, S., and Carson, J. (2017). Leisure in a post-work society. World Leisure Journal, 59(3), 184-94.

Spracklen, K., Lashua, B., Sharpe, E., and Swain, S. (Eds) (2017). The Palgrave handbook of leisure theory. London: Palgrave Macmillan.

Stebbins, R.A. (1982). Serious leisure: a conceptual statement. Pacific Sociological Review (now Sociological Perspectives), 5(3), 251-272.

Stebbins, R.A. (2018). The sociology of leisure: an estranged child of mainstream sociology. International Journal for the Sociology of Leisure, 1(1), 43-53.

Stebbins, R.A., and Graham, M. (Eds) (2004). Volunteering and leisure/leisure as volunteering. Wallingford, UK: CABI Publishing.

Taylor, P. (Ed.) (2011). Torkildsen's sport and leisure management. London: Routledge.

Van Moorst, H. (1982). Leisure and social theory. Leisure Studies, 1(2), 157-170.

Veal, A.J. (2011). The leisure society I: myths and misperceptions, 1960-1979. World Leisure Journal, 53(3), 206-227.

Veal, A.J. (2012). The leisure society II: the era of critique, 1980-2011. World Leisure Journal, 54(2), 99-140.

Veal, A.J. (2018). Whatever happened to the leisure society? London: Routledge.

Wearing, B. (1998). Leisure and feminist theory. London: Sage.

Zuzanek, J. (2003). What will leisure be? Homage to Joffre Dumazedier (1915-2002). Loisir et Société, 26(1), 280.

Zuzanek, J. (2006). Leisure and time. In C. Rojek, S. Shaw and A.J. Veal (Eds), A Handbook of leisure studies (pp. 185-202). Basingstoke, UK: Palgrave Macmillan. 


\section{Notes}

${ }^{\mathrm{i}}$ The reference to the Dumazedier definition by McClean et al. (2005) is third-hand. They attribute it to the International Group for Leisure Social Sciences (see note iii), but the source they give is Cosgrove and Jackson (1972: 13). This source, however, while acknowledging the IGLSS, does not reference any specific publication. It can only be surmised that the original source was Dumazedier (1960).

ii It should be noted that a feature of the French language is that the possessive pronoun (sa, son) takes the gender of the object noun to which it is attached, rather than that of the possessor. The French version of the definition is therefore gender-neutral as regards the person enjoying the leisure. However, in the1967 English translation of Dumazedier's book, and in his 1960 article, sa/son was translated throughout as the male 'he' or 'his'. In a modern translation a gender-neutral format would be more likely to be used, such as: 'her/his'; 'her or his'; alternating between male and female; or avoiding the issue by using a plural format. Although pre-1970s writings are typically granted some license, Dumazedier, and those who quote him, may unwittingly be perceived as being guilty of 'linguistic male bias' (see, for example, Griffin et al., 1982: 91).

iii The International Group for Leisure Social Sciences evolved into the International Sociological Association's still existing Research Committee 13 (Dumazedier, 1967: 280), of which Dumazedier was the founding chair.

iv Translations other than the published English versions of Dumazedier's books, are attributable to fading memories of 1950s 'O-level' French studied in the UK, efficiently supplemented by 'Google Translate'. This limited competency with the French language limited the ability of the author to engage with works not available in English translation.

v This also resonates with the Universal Declaration of Human Rights, in which Article 27 refers to the right 'freely to participate in the cultural life of the community' or 'prendre part librement à la vie culturelle de la communauté'.

vi As with the 1962/1967 book, there is, however, a curious difference between the titles of the French and English editions. The French edition includes the sub-title Critique et contre-critique de la civilisation du loisir, but this is omitted in the English edition. While a brief discussion of the leisure civilisation is included, in both editions (Dumazedier, 1974a: 148-150; 1974b: 185-187), this hardly measures up to the promise of the sub-title.

vii It is possible that this division might be viewed differently in the original French since, as Mommaas (1997: 242) has pointed out, 'free time' (temps libre) is more commonly used conversationally in French than 'leisure' (loisir), so treating leisure as special type of activity might make more sense than it does in English.

viii In fact, of over 30 references listed, only five are actually cited in the text.

ix The 'bitter criticism' was referenced to Lanfant (1972), but it has not been possible to consult this publication. 